\title{
Phytoplankton communities in freshwater rock pools: structural and spatial dynamics in Brazilian drylands
}

\author{
Kelly Dayane Pereira da Silva ${ }^{1}$, Nadson Ressyé Simões ${ }^{2}$, Danielle Lima de Oliveira ${ }^{1}$, Fátima \\ dos Santos Silva ${ }^{1}$ and Luciana Gomes Barbosa ${ }^{1, *}$ \\ ${ }^{1}$ Centro de Ciências Agrárias, Universidade Federal da Paraíba - Campus II, Centro de Ciências Agrárias, \\ Núcleo de Pesquisas em Limnologia (NULIBAC), Rodovia PB-079, Areia - PB, CEP: 58397-000, Brazil. \\ 2 Centro de Formação em Ciências e Tecnologias Ambientais, Universidade Federal do Sul da Bahia (UFSB), \\ Porto Seguro, BR-367 - km 10 - CEP 45810-000, Brazil. \\ * Corresponding author: lucianabarbosa@cca.ufpb.br
}

Received: 16/08/18 Accepted: 26/09/19

\begin{abstract}
Phytoplankton communities in freshwater rock pools: structure and spatial dynamics in Brazilian drylands

Models associating the responses of the plankton community with the metacommunity structure have expanded our understanding of the frequency with which dispersal-related mechanisms are associated with these responses, which depend on the local characteristics of the habitat and the degree of connectivity between habitats. Our study patterns in the phytoplankton community structure of freshwater rock pools in dryland ecosystems of northeast Brazil. We hypothesized that depending on the degree of isolation between rock pools, functional groups would be better indicators of the isolation gradients than would species, with a decrease in the similarity between communities with increasing distance. We sampled 20 rock pools across a region with rainfall $<300 \mathrm{~mm} / \mathrm{yr}$ (Paraíba, Brazil), and identified 55 taxa in 13 functional groups. Cyanobacteria dominated in 10 of the 20 rock pools, which were shallow $(\leq 1.5 \mathrm{~m})$ and slightly acidic to alkaline (pH 5.8-10.3). The Jaccard similarity index showed no correlation with the distance between rock pools, suggesting that isolation did not influence the species composition, although a highly stochastic distribution was observed. A synergy among local structuring factors (size, depth, light limitation) and spatial (dispersal) factors appears to best explain distribution and structure of the phytoplankton communities in these freshwater rock pools.
\end{abstract}

Key words: diversity, functional groups, inselbergs, shallow environments, drylands, stochasticity

\section{RESUMEN}

Comunidades de fitoplancton en charcas de roca de agua dulce: estructura y dinámica espacial en las tierras secas brasileñas

Los modelos que asocian las respuestas de la comunidad de plancton con la estructura de las metacomunidades han ampliado nuestra comprensión de la frecuencia con la cual los mecanismos relacionados con la dispersión son asociados con estas respuestas, las cuales dependen de las características locales del hábitat y su grado de conectividad. La capacidad de dispersión es un rasgo especifico de las especies. Nuestro estudio tuvo como objetivo identificar patrones en la estructura de la comunidad de fitoplancton en los ecosistemas de charcas de rocas de agua dulce de las tierras secas en el noreste brasileño. Probamos la hipótesis que, dependiendo del grado de aislamiento entre charcas de roca, los grupos funcionales (GFs) serán mejores indicadores de los gradientes que las especies, junto a la disminución de la similitud con el aumento en la distancia. Muestreamos 20 charcas de roca, distribuidas en una región con una precipitación < 300 mm/año (Paraíba, Brasil). Las cianobacterias dominaron en 10 de las 20 charcas de rocas, todos los cuales podrían caracterizarse como poco profundos ( $\leq 1.5 \mathrm{~m}$ ), y aguas ligeramente ácidas a alcalinas (pH 5.8-10.3). Identificamos 55 taxones distribuidos en 13 GFs. El indice de similitud de Jaccard no mostró correlación con la distancia entre las charcas de roca, lo que sugiere que el aislamiento no influyó en la composición de las especies, aunque una distribución altamente estocástica fue observada. La sinergia entre los factores estructuradores locales (tamaño, profundidad, limitación de la luz) y los factores espaciales 
(dispersión) pueden ser los mejores paradigmas que explican la distribución y estructura de las comunidades de fitoplancton en las charcas de roca analizadas.

Palabras clave: diversidad, grupos funcionales, inselbergs, ambientes poco profundos, tierras áridas, estocasticidad

\section{INTRODUCTION}

Classical ecological studies have traditionally considered communities as closed and isolated units (e.g., Leibold et al., 2004). Considerable progress has been made in understanding community attributes such as richness, diversity, and other factors that contribute to niche processes (Shurin \& Srivastava, 2005), including regional factors and/or neutral dynamics (Hubbell, 2001; Shurin \& Srivastava, 2005). From a regional perspective, two simultaneous processes shape local communities: the dispersal of species between habitats and the interactions between species and their environment within the same habitat (Shurin et al., 2000; Gonzalez et al., 2009; Winegardner, 2012).

Studies of shallow natural lakes using the metacommunity approach for phytoplankton (Vanormelingen et al., 2008) and zooplankton (Cottenie \& Meester, 2003; Michels et al., 2001; Shurin et al., 2000) have identified trends regarding which processes are most important in structuring small communities. In the case of phytoplankton, Soininen et al. (2007) found that communities were structured first by the ion concentration, second by nitrogen, and finally by geographic location. Beisner et al. (2006) showed that species with a larger body size and limited mobility (e.g., fish and zooplankton) are more influenced by spatial factors than are species considered good dispersers, such as bacteria and phytoplankton. These results suggest that zooplankton and fish are restricted by dispersal mechanisms and may therefore act as metacommunities within the landscape.

Regions with temporally and spatially uneven rainfall, high temperatures, and high evaporation rates exhibit a negative water balance, resulting in the predominance of temporary, unstable aquatic ecosystems in the landscape (e.g., Williams, 1997). These temporary ecosystems might be considered islands in the semi-arid landscape, due to their ephemeral nature and instability, and are highly important for local and regional conservation of species (Maltchik, 2000). These waterbodies have been used as model systems in ecological and evolutionary research, due to their simple structure, which facilitates the experimental design. In addition, these water bodies allow a relatively simple but realistic quantification of important processes that structure populations and communities, compared to larger and more-complex aquatic ecosystems (Jocque et al., 2010; Brendonck et al., 2010).

Freshwater rock pools are mostly temporary habitats typical of arid climates (Kluge \& Büdel, 2013) and are commonly formed on inselbergs (rocky reliefs or pediplains) (Jatobá, 1994). They are present in Western Australia and the Ivory Coast (Brendonck et al., 2010), and exhibit varying degrees of isolation and connectivity (Jocque et al., 2010). The resident species are highly adapted to the conditions of small water volume, high temperatures, and high ion concentrations. Because rock pools are highly unstable systems, knowledge of the spatio-temporal variability of the hydroperiod is essential to understand the dynamics of their aquatic communities (Hulsmans et al., 2008).

Freshwater rock pools are typically completely isolated from each other, making active dispersal difficult, while passive dispersal mediated by other organisms (Havel \& Shurin, 2004; Brendonck et al., 2010; Genitsaris et al., 2011) may be affected by the distance between pools. In addition, because high evaporation is a severe environmental condition, these communities exhibit a low diversity of species and functional groups.

This scenario of a high degree of isolation, restricted dispersal and low species diversity is ideal for understanding the mechanisms that enable species to persist in stressful environments. The objective of our study was to characterize the phytoplankton communities of ephemeral freshwater rock pools and to identify patterns 
in the community structure. We hypothesized that, depending on the degree of isolation between the rock pools, functional groups would be better indicators of the isolation gradient than species, with a decrease in similarity with an increase in distance.

\section{MATERIALS AND METHODS}

\section{Study area}

The study was carried out in the Caatinga Morpho-climatic Domain, in the Borborema mesore- gion and the Eastern Cariri microregion $\left(07^{\circ} 29^{\prime}\right.$ $20^{\prime \prime} \mathrm{S}, 36^{\circ} 17^{\prime} 14^{\prime \prime} \mathrm{W}$ ) of Paraíba state, Brazil (Fig. 1; Fig. 2). The predominant climate is hot semi-arid (BSh) (Alvares et al., 2013), with a mean annual temperature $>20^{\circ} \mathrm{C}$ and the lowest mean annual rainfall in Brazil, which was $\leq 77.3$ $\mathrm{mm}$ during the sampling period.

This region comprises an open arboreal-shrub caatinga with many granite formations, where mostly shallow temporary pools occur (Altermatt et al., 2003). Although a low absorption potential and moisture retention are characteristics of this environment, due to the rocky substrate and unfa-
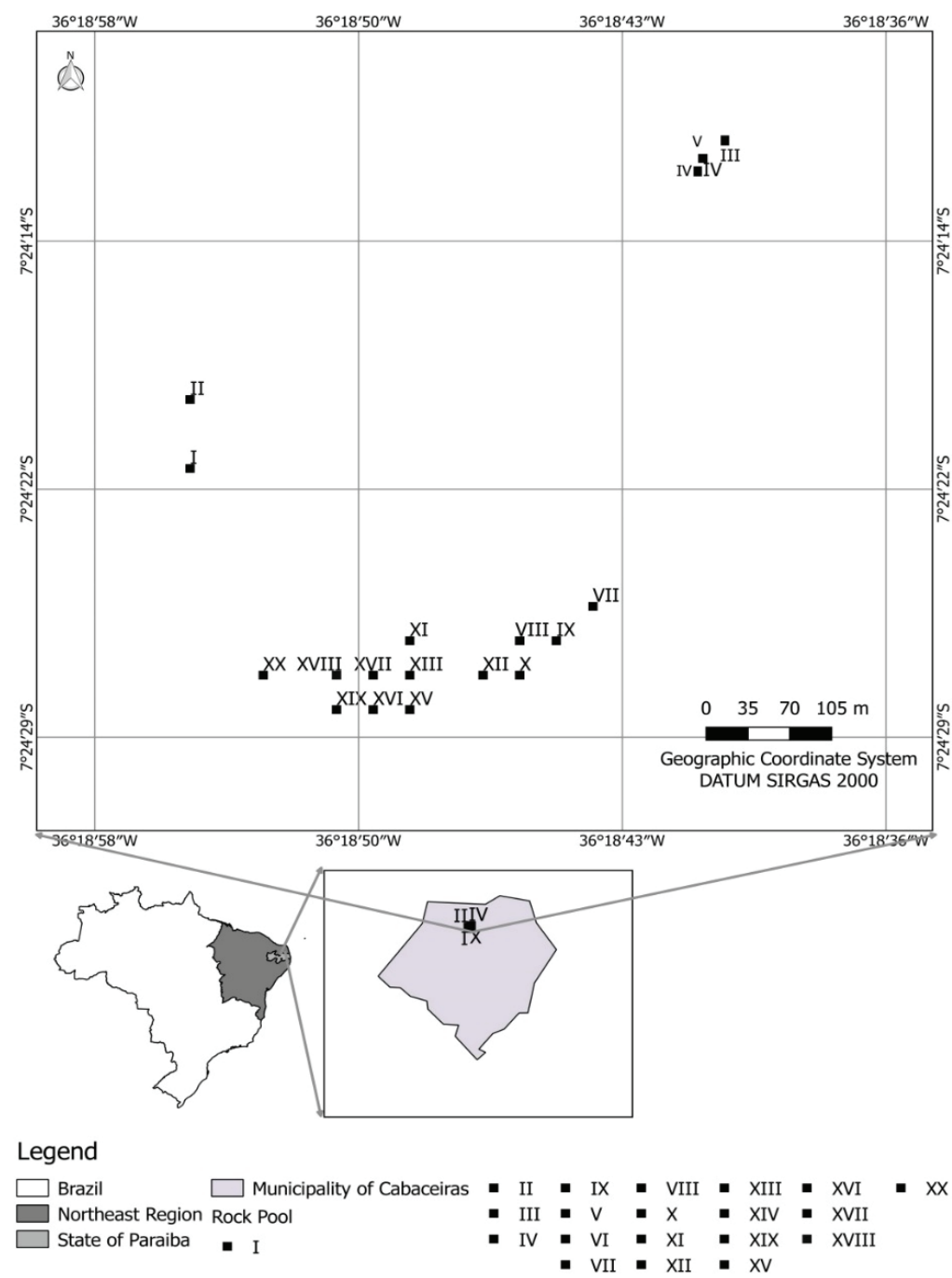

Figure 1. Location of the study area in northeastern Brazil. Ubicación del área de estudio. 
vorable climate, Porembski (2007) described the formation of temporary rock pools during the rainy season.

\section{Sampling}

Water samples for analyses of physical, chemical and biological parameters were collected from the subsurface in 20 rock pools on inselbergs in the Cabaceiras region, during the rainy season.

\section{Limnological characterization: analysis of local variables}

To characterize the habitats, temperature $\left({ }^{\circ} \mathrm{C}\right)$, $\mathrm{pH}$, dissolved oxygen ( $\mathrm{mg} / \mathrm{l})$, turbidity, and total dissolved solids were measured in situ, using aHanna Instruments HI 98130 portable multiparameter probe. Water transparency $\left(\mathrm{Z}_{\mathrm{DS}}\right)$ was determined based on the Secchi depth (m) (Cole, 1994). The coefficient of vertical light attenuation (k) was calculated as $\mathrm{k}=1.7 \times \mathrm{Z}_{\mathrm{DS}^{-1}}$ (Poole \& Atkins, 1929). The euphotic zone $\left(Z_{\mathrm{eu}}=\right.$ Sech disk * 2.7) was calculated according to Cole (1994). Due to the isothermal profile and shallow depth, the mixing zone $\left(Z_{\text {mix }}\right)$ was considered as the maximum depth $\left(Z_{\max }\right)$. The $Z_{\mathrm{eu}}: Z_{\text {mix }}$ ratio was used as an index of light availability in the mixing zone (Jensen et al., 1994).

\section{Analysis of the phytoplankton community}

Water samples for analysis of the phytoplankton community were collected from the subsurface in the limnetic zone and fixed with Lugol solution. Phytoplankton was quantified according to Utermöhl (1958), and the sedimentation rate was determined following Lund et al. (1958).

The biovolume $\left(\mu \mathrm{m}^{3} / \mathrm{ml}^{\rightarrow} \mathrm{mm}^{3} / \mathrm{l}\right)$ of each species was calculated based on Sun \& Liu (2003) and Hillebrand et al. (1999). Functional groups were defined according to Reynolds et al. (2002) and Padisák et al. (2009).

\section{Statistical analyses}

To estimate diversity we employed the concepts of $\alpha, \beta$ and $\gamma$ described by Whittaker (1972) and revised by Jurasinkii et al. (2009): $\alpha$ diversity (or site-associated diversity), within a particular community or area; $\beta$ diversity (or species replacement), the extent of change in the community composition along an environmental gradient; and $\gamma$ diversity, which represents the species richness for a set of habitats and therefore reflects the geographic diversity (Hunter \& Nosratinia, 2002). Richness, diversity and equitability were estimated for both species and functional groups. Species diversity was estimated
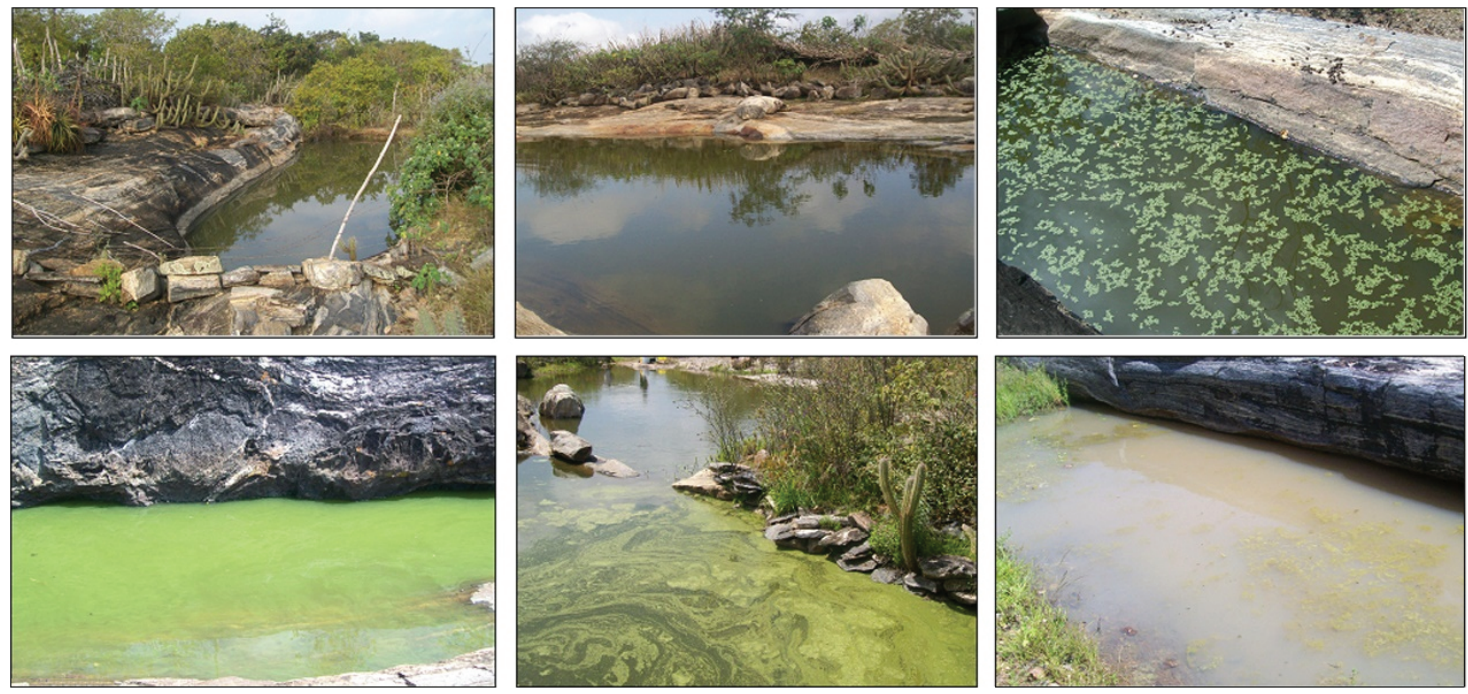

Figure 2. Rock-pool habitats in the study in northeastern Brazil. Charcas de rocas en el área de estudio (Noreste de Brasil). 
Table 1. Environmental variables sampled in 20 rock pools in northeastern Brazil. Variables ambientales muestreadas en 20 grupos de rocas, en el noreste de Brasil.

\begin{tabular}{|c|c|c|c|c|c|c|c|c|c|c|}
\hline $\begin{array}{l}\text { Rock } \\
\text { pool }\end{array}$ & Location & $\begin{array}{l}\text { Depth } \\
\text { (m) }\end{array}$ & $\begin{array}{c}\text { Transparency } \\
\text { (m) }\end{array}$ & $\mathbf{Z}_{\mathrm{eu}}$ & $\mathbf{Z}_{\mathrm{eu}}: \mathbf{Z}_{\mathrm{mix}}$ & $\begin{array}{c}\text { Light } \\
\text { attenuation } \\
\text { vertical } \\
\text { coefficient }\end{array}$ & $\begin{array}{c}\text { Temperature } \\
\left({ }^{\circ} \mathrm{C}\right)\end{array}$ & pH & Richness & $\begin{array}{l}\text { Phytoplankton } \\
\text { biomass(mg/l) }\end{array}$ \\
\hline I & $\begin{array}{c}07^{\circ} 24^{\prime} 21 " \mathrm{~S} ; \\
036^{\circ} 18^{\prime} 55^{\prime \prime} \mathrm{W}\end{array}$ & 5 & 0.5 & 1.5 & 0.3 & 5.7 & 23.9 & 5.8 & 12 & 11.445880 \\
\hline II & $\begin{array}{c}07^{\circ} 24^{\prime} 19^{\prime \prime} \mathrm{S} ; \\
036^{\circ} 18^{\prime} 55^{\prime \prime} \mathrm{W}\end{array}$ & 5 & 0.6 & 1.7 & 0.3 & 5.7 & 29.5 & 9.3 & 8 & 134.767276 \\
\hline III & $\begin{array}{c}07^{\circ} 24^{\prime} 12^{\prime \prime S} \\
036^{\circ} 18^{\prime} 41 " \mathrm{~W}\end{array}$ & 2.5 & 0.3 & 0.9 & 0.4 & 4.3 & 27.8 & 6.9 & 10 & 19.088 \\
\hline IV & $\begin{array}{c}07^{\circ} 24^{\prime} 12^{\prime \prime S} \\
036^{\circ} 18^{\prime} 41^{\prime \prime} \mathrm{W}\end{array}$ & 2 & 0.5 & 1.5 & 0.8 & 2.1 & 27.8 & 7.4 & 8 & 920 \\
\hline V & $\begin{array}{c}07^{\circ} 24^{\prime} 12^{\prime \prime} \mathrm{S} \\
036^{\circ} 18^{\prime} 41^{\prime \prime W}\end{array}$ & 0.5 & 0.7 & 2.1 & 4.2 & 0.4 & 25.1 & 6.3 & 9 & 2.855 \\
\hline VI & $\begin{array}{c}07^{\circ} 24^{\prime} 12^{\prime \prime S} \\
036^{\circ} 18^{\prime} 41^{\prime \prime W}\end{array}$ & 2.5 & 0.2 & 0.7 & 0.3 & 5.7 & 29.6 & 6.2 & 5 & 2.975 \\
\hline VII & $\begin{array}{c}07^{\circ} 24^{\prime} 25^{\prime \prime} \mathrm{S} \\
036^{\circ} 18^{\prime} 44^{\prime \prime} \mathrm{W}\end{array}$ & 4 & 0.5 & 1.5 & 0.4 & 4.3 & 31.1 & 6.8 & 7 & 1.656992 \\
\hline VIII & $\begin{array}{c}07^{\circ} 24^{\prime} 26^{\prime \prime} \mathrm{S} \\
036^{\circ} 18^{\prime} 46^{\prime \prime} \mathrm{W}\end{array}$ & 4 & 1 & 3 & 0.8 & 2.1 & 30.6 & 6.5 & 11 & 3.449503 \\
\hline IX & $\begin{array}{c}07^{\circ} 24^{\prime} 26^{\prime \prime S} \\
036^{\circ} 18^{\prime} 45^{\prime \prime} \mathrm{W}\end{array}$ & 3 & 0.5 & 1.5 & 0.4 & 3.4 & 28.9 & 7.9 & 9 & 48.646 \\
\hline $\mathrm{X}$ & $\begin{array}{c}07^{\circ} 24^{\prime} 27^{\prime \prime S} \\
036^{\circ} 18^{\prime} 46^{\prime \prime} \mathrm{W}\end{array}$ & 3 & 0.3 & 1 & 0.3 & 5.7 & 30 & 10.3 & 4 & 5.244 \\
\hline XI & $\begin{array}{c}07^{\circ} 24^{\prime} 26^{\prime \prime S} \\
036^{\circ} 18^{\prime} 49^{\prime \prime} \mathrm{W}\end{array}$ & 5 & 0.7 & 2 & 0.3 & 5.7 & 32.9 & 9.4 & 8 & 4.904 \\
\hline XII & $\begin{array}{c}07^{\circ} 24^{\prime} 27^{\prime \prime} \mathrm{S} \\
036^{\circ} 18^{\prime} 47^{\prime \prime} \mathrm{W}\end{array}$ & 4 & 0.6 & 1.8 & 0.5 & 3.4 & 33.4 & 8.4 & 11 & 57.315 \\
\hline XIII & $\begin{array}{c}07^{\circ} 24^{\prime} 27^{\prime \prime} \mathrm{S} \\
036^{\circ} 18^{\prime} 49^{\prime \prime} \mathrm{W}\end{array}$ & 3.5 & 1.5 & 4.5 & 1.3 & 1.3 & 30.8 & 7.4 & 8 & 118.041 \\
\hline XIV & $\begin{array}{c}07^{\circ} 24^{\prime} 28^{\prime \prime} \mathrm{S} \\
036^{\circ} 18^{\prime} 49^{\prime \prime} \mathrm{W}\end{array}$ & 2.5 & 0.2 & 0.6 & 0.3 & 5.7 & 31.1 & 7.2 & 6 & 2.679 \\
\hline $\mathrm{XV}$ & $\begin{array}{c}07^{\circ} 24^{\prime} 28^{\prime \prime} \mathrm{S} \\
036^{\circ} 18^{\prime} 49^{\prime \prime} \mathrm{W}\end{array}$ & 3.5 & 0.5 & 1.5 & 0.4 & 4.3 & 28.6 & 7.1 & 15 & 332.859 \\
\hline XVI & $\begin{array}{c}07^{\circ} 24^{\prime} 28^{\prime \prime} \mathrm{S} \\
036^{\circ} 18^{\prime} 50^{\prime \prime} \mathrm{W}\end{array}$ & 4 & 0.7 & 2.1 & 0.5 & 3.4 & 30.5 & 7 & 6 & 54.836 \\
\hline XVII & $\begin{array}{c}07^{\circ} 24^{\prime} 27^{\prime \prime} \mathrm{S} \\
036^{\circ} 18^{\prime} 50^{\prime \prime} \mathrm{W}\end{array}$ & 4 & 0.5 & 1.5 & 0.4 & 4.3 & 27.2 & 8 & 10 & 545 \\
\hline XVIII & $\begin{array}{c}07^{\circ} 24^{\prime} 27^{\prime \prime S} \\
036^{\circ} 18^{\prime} 51 " \mathrm{~W}\end{array}$ & 4.5 & 0.5 & 1.5 & 0.3 & 5.7 & 32.6 & 7.3 & 12 & 46 \\
\hline XIX & $\begin{array}{c}07^{\circ} 24^{\prime} 28^{\prime \prime S} \\
036^{\circ} 18^{\prime} 51 " \mathrm{~W}\end{array}$ & 1 & 0.4 & 1.2 & 1.2 & 1.4 & 34.6 & 7.6 & 13 & 10.279 \\
\hline$X X$ & $\begin{array}{c}07^{\circ} 24^{\prime} 27^{\prime \prime} \mathrm{S} \\
036^{\circ} 18^{\prime} 53^{\prime \prime} \mathrm{W}\end{array}$ & 3.5 & 0.3 & 0.9 & 0.3 & 5.7 & 32.2 & 9.3 & 6 & 25.252 \\
\hline
\end{tabular}


with the Shannon diversity index (Shannon \& Weaver, 1963) using biomass data and expressed in bits $\mathrm{mg} / \mathrm{l}$, and equitability (J) was calculated according to Pielou (1966). Since a common characteristic of these communities is the presence of rare species, we used the second-order Jackknife index to estimate species richness (Magurran, 2004).

Cluster analysis was performed using the Jaccard distance index (Jaccard, 1908) and the UPGMA (Unweighted Pair-Group Method with Average mean) algorithm (Sneath \& Sokal, 1973), which was selected based on the high cophenetic correlation coefficient, in order to compare the compositional similarity between communities and functional groups. The Jaccard index-based distance matrix was also used to analyze the percentage of species shared between communities (Legendre \& Legendre, 1998).

To analyze the correlation between the community attributes and the distance between rock pools, we conducted Mantel tests between response matrices (a matrix of community attributes and a matrix of dissimilarity) and a matrix representing spatial distance, generated according to the Euclidean distances between the geographic coordinates of each rock pools. Therefore, we used geographical coordinates obtained in the field to create distance between rock pools, as a potential dispersal route estimative of phytoplankton communities. All statistical analyses were performed with the $\mathrm{R}$ statistical package ( $\mathrm{R}$ Core Team, 2017).

\section{RESULTS}

\section{Physical and chemical factors}

The freshwater rock pools were small and shallow, with a maximum depth of approximately $5 \mathrm{~m}$. In general, water transparency was low $(\leq 1.5 \mathrm{~m})$ and the euphotic zone was shallow $(\leq 4.5 \mathrm{~m})$ (Table 1). Light penetration was limited $\left(\mathrm{Z}_{\mathrm{eu}}: \mathrm{Z}_{\mathrm{mix}} \leq 1\right)$ in most pools except for pools $\mathrm{V}$,

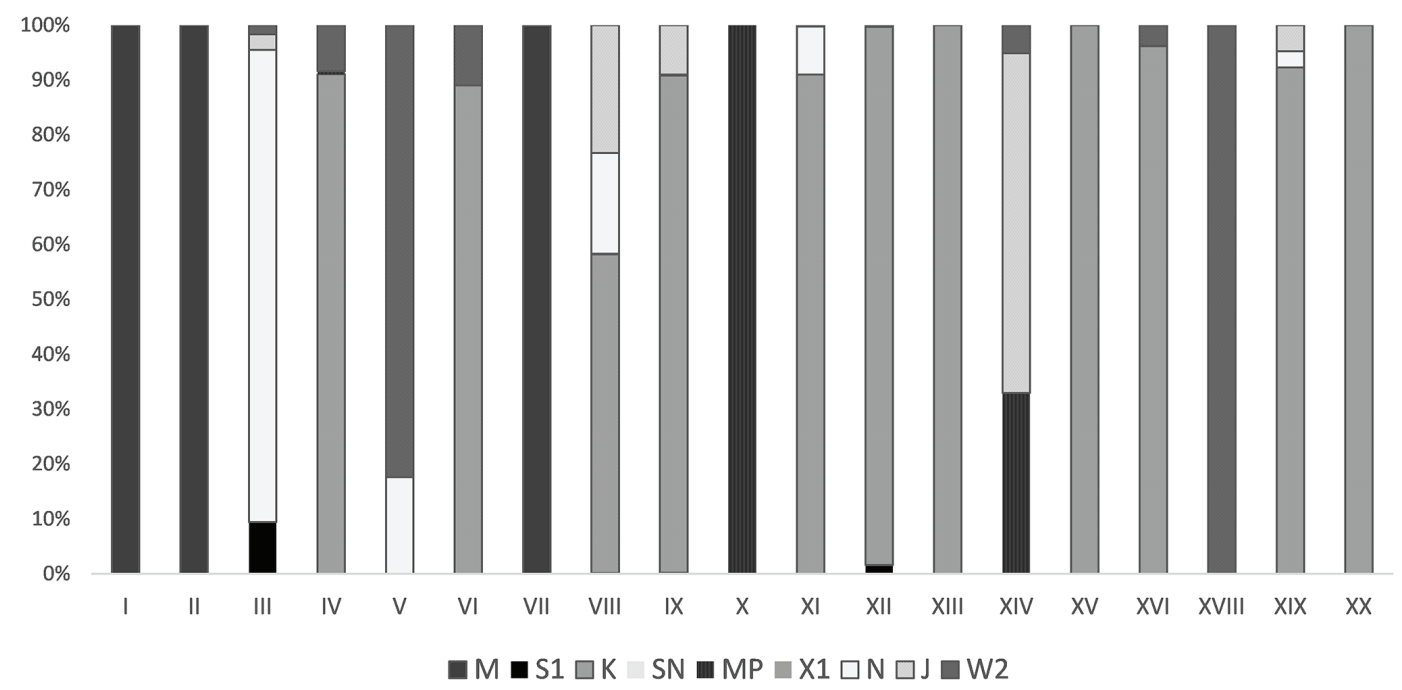

Figure 3. Relative biomass (\%) of the phytoplankton functional groups ( $\geq 80 \%$ of the total contribution) in 20 rock pools in northeastern Brazil. Biomasa relativa (\%) de los grupos funcionales de fitoplancton ( $\geq 80 \%$ de la contribución total) en 20 grupos de rocas, en el Noreste de Brasil. Functional groups and representative species: M: composed to large colonies of the Cyanobacteria such as Microcystis sp.; $\mathrm{S}_{1}$ : shade-adapted cyanoprokaryotes, including Planktolyngbya limnetica and Pseudanabaena sp.; K: includes small-celled such as Aphanocapsa sp.; $\mathrm{L}_{\mathrm{O}}$ : small dinoflagellates and cyanobacterias such as Merismopedia sp.; $\mathrm{S}_{\mathrm{N}}$ : nitrogen-fixing species, among these Cylindrospermopsis raciborskii; MP: metaphytic, periphytic and epilithic diatoms (eg. Eunotia sp. and Gomphonema sp.); $\mathrm{X}_{1}$ : group is formed for small and unicellular chlorococcaleans, such as Monoraphidium sp.; N: Small desmids, typical from mesotrophic ecosystems (eg. Euastrum sp.); J: colonial green algae (eg. Scenedesmus sp.); W2: small Euglenoids, among these Trachelomonas volvocina; A: Centric diatoms, small and planktonic (eg. Cyclotella sp.); D: Small or medium-sized diatom, including Synedra sp. and T: filamentous algae including Mougeotia sp. (Reynolds et al., 2002; Padisák et al., 2009). 
XIII, and XIX ( $\left.\mathrm{Z}_{\mathrm{eu}}: \mathrm{Z}_{\mathrm{mix}} \geq 1\right)$, where Chara martiana J Wallman 1853 was present. Subsurface temperatures were high, and the $\mathrm{pH}$ ranged from acidic to alkaline (minimum of 5.8 and maximum of 10.2) (Table 1).

\section{Phytoplankton}

We identified 55 species and morphospecies, of which 23 could be assigned to one of the following 13 functional groups: $\mathrm{M}, \mathrm{S}_{1}, \mathrm{~K}, \mathrm{~L}_{\mathrm{O}}, \mathrm{S}_{\mathrm{N}}, \mathrm{M}_{\mathrm{P}}$, $\mathrm{X}_{1}, \mathrm{~N}, \mathrm{~J}, \mathrm{~W}_{2}, \mathrm{~A}, \mathrm{D}$ and T. As shown in Figure 3, functional group $\mathrm{M}$, represented by Microcystis sp., showed the highest biomass and dominance, particularly in pools I $(22.8 \mathrm{mg} / \mathrm{l}), \mathrm{II}(269.5 \mathrm{mg} / \mathrm{l})$ and VII $(2365.2 \mathrm{mg} / \mathrm{l})$.

\section{Taxonomic diversity at local and regional scales}

Of the 55 taxa recorded, 44 were considered rare (frequency of occurrence $<20 \%$ ), nine occasional (frequency of occurrence between $20 \%$ and 50 $\%$ ), and two common (frequency of occurrence $>$ $50 \%$ ). Based on the second-order Jackknife index, species richness in this region reached 92 taxa, due to a large number of rare species.

Only Aphanocapsa sp. and Trachelomonas volvocina, attributed respectively to functional groups $\mathrm{K}$ and $\mathrm{W}_{2}$, were recorded in more than 50 $\%$ of the samples. The species accumulation curve did not stabilize which supported the extrapolation of the species richness and demonstrated that further sampling in the region is needed.

The richness of species ( $\alpha$ diversity) ranged from four to 15 , whereas the richness of functional groups ranged from four to 10 (Table 2). The Shannon-Weaver diversity index for species ranged from 0.0002 to 1.9 bits $\mathrm{mg} / \mathrm{l}$ (respectively, rock pools XVIII and II), and for functional groups ranged from 0.0002 to 1.6 bits $\mathrm{mg} / \mathrm{l}$ (respectively, rock pools IV and VII). Equitability values were slightly higher for functional groups than for species (Table 2).

All metrics for species were correlated with their respective metric for functional groups; the correlation for richness was 0.76 , for diversity 0.91 , and for uniformity 0.90 . Biomass $(\mathrm{mg} / \mathrm{l})$ was negatively correlated with the Shannon-Weaver diversity index and the equitability for both species and functional groups.

The Jaccard index based on species showed a low compositional similarity among the communities, with a high mean dissimilarity $(0.81 \pm$ 0.10 ). Only five pairs of pools shared more than $50 \%$ of the species, 78 pairs shared $20-50 \%$, while 102 pairs shared less than $20 \%$ of the

Table 2. Functional groups, taxonomic groups and phytoplankton diversity sampled in 20 natural pool sites in northeastern Brazil. Grupos funcionales, grupos taxonómicos y diversidad de fitoplancton muestreados en 20 piscinas naturales en el noreste de Brasil.

\begin{tabular}{ccccccc}
\hline & \multicolumn{2}{c}{$\begin{array}{c}\text { Richness } \\
\text { (Index) }\end{array}$} & \multicolumn{2}{c}{$\begin{array}{c}\text { Shannon-Weaver } \\
\text { diversity index }\end{array}$} & \multicolumn{2}{c}{ Evenness } \\
& $\begin{array}{r}\text { Taxonomic } \\
\text { Groups }\end{array}$ & $\begin{array}{r}\text { Functional } \\
\text { Groups }\end{array}$ & $\begin{array}{r}\text { Taxonomic } \\
\text { Groups }\end{array}$ & $\begin{array}{r}\text { Functional } \\
\text { Groups }\end{array}$ & $\begin{array}{c}\text { Taxonomic } \\
\text { Groups }\end{array}$ & $\begin{array}{c}\text { Functional } \\
\text { Groups }\end{array}$ \\
\hline Minimum & 4.0 & 4.0 & 0.0002 & 0.0002 & 0.0001 & 0.0001 \\
Firstquartile & 6.7 & 6.0 & 0.3 & 0.3 & 0.1 & 0.1 \\
Median & 8.5 & 6.0 & 0.5 & 0.5 & 0.3 & 0.3 \\
Average & 8.8 & 6.5 & 0.64 & 0.5 & 0.3 & 0.3 \\
Thirdquartile & 10.2 & 7.0 & 0.9 & 0.7 & 0.4 & 0.4 \\
Maximum & 15.0 & 10.0 & 1.9 & 1.6 & 0.7 & 0.8 \\
\hline
\end{tabular}




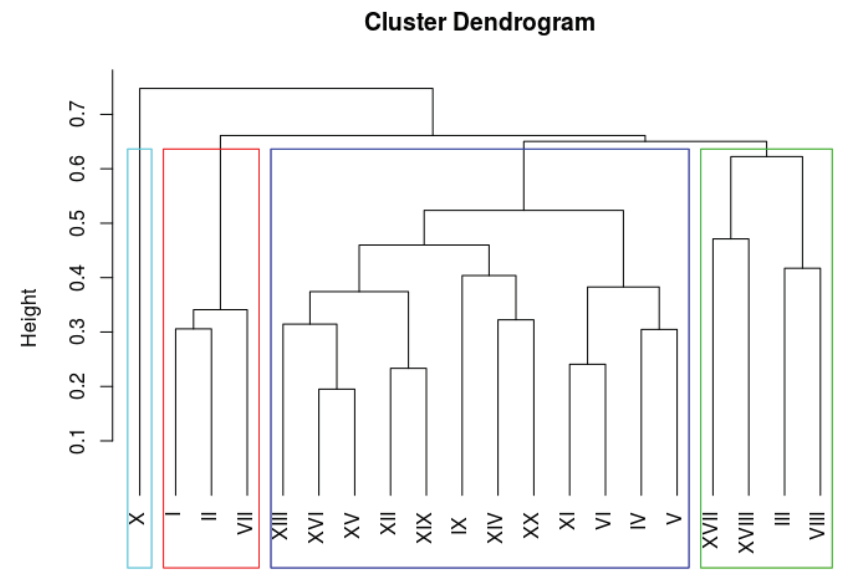

20 sites
4 groups

Figure 4. Cluster analysis from the relative biomass $(\mathrm{mg} / \mathrm{l})$ of the phytoplankton species in 20 rock pools in northeastern Brazil. Análisis de conglomerados de la biomasa relativa $(\mathrm{mg} / \mathrm{ll}$ ) de las especies de fitoplancton en 20 grupos de rocas, en el Noreste de Brasil.

species. Mean dissimilarity based on the Jaccard index for functional groups was $0.57( \pm 0.15)$. Sixty-four pairs of pools shared more than $50 \%$ of the functional groups, 115 pairs shared $20-50$ $\%$, and only 11 pairs shared less than $20 \%$.

Cluster analysis showed well-defined groups, mainly associated with the morphologies and adaptive strategies of species and functional groups (Fig. 4 and Fig. 5). Cluster analysis based on species showed three groups: Group 1 (Pools I, II and VII), characterized by low diversity, high biomass, and a dominance of some colonial species such as Microcystis sp. and Aphanocapsa sp.; Group 2 (Pools III, VIII, XVII and XVIII), characterized by filamentous species such as Spirogyra sp. and Planktolyngbya limnetica; and Group 3 (Pools IV, V, VI, IX, XI, XII, XIII, XIV, $\mathrm{XV}, \mathrm{XVI}, \mathrm{XIX}$ and XX), with a considerable morphological divergence, including colonial (Chlorococcales sp., Desmodesmus sp., Scenedesmus sp.), flagellate (Hyalophacus ocellatus) and unicellular (Staurastrum leptocladum) species (Fig. 4). Cluster analysis based on functional groups also showed three groups (Fig. 5): Group 1, characterized by functional groups $\mathrm{K}$, $\mathrm{M}_{\mathrm{P}}, \mathrm{J}, \mathrm{W}_{2}$ and $\mathrm{T}$, which had wide morphological diversity; Group 2, characterized by functional groups $\mathrm{X}_{1}, \mathrm{~J}$ and $\mathrm{N}$, comprising colonial, singlecelled chlorophytes and unicellular desmids; and Group 3, characterized by functional groups $\mathrm{S}_{\mathrm{N}}$ and $\mathrm{M}$, comprising filamentous and colonial cyanobacteria.

There was a significant correlation (Mantel test $=0.47, p=0.001$ ) between the dissimilarity matrices of the rock pools based on the composition of species and of functional groups. Among the community attributes that we assessed (species richness, Shannon diversity index, equitability and abundance), only species richness was correlated with the distances between pools (Mantel test $=0.40, p<0.02$ ), indicating that: (i) rock pools closer to each other diverged less in species richness, and (ii) increased distance between pools resulted in an increased between-pool difference in species richness.

\section{DISCUSSION}

Our results indicated a considerable discontinuity in the spatial distribution of the phytoplankton communities and functional groups among these freshwater rock pools. This pattern accords with the characteristics described for neutral distributions, whereby communities are structured by 


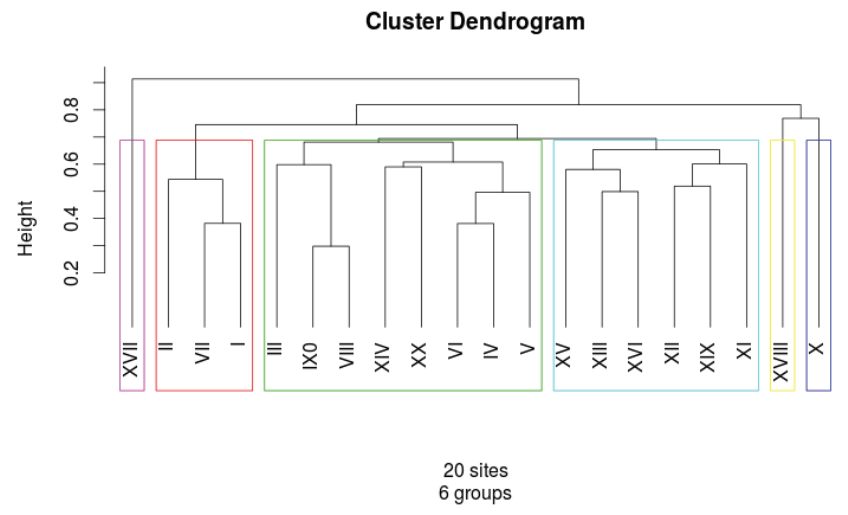

Figure 5. Cluster analysis from the relative biomass $(\mathrm{mg} / \mathrm{l})$ of the phytoplankton functional groups in 20 rock pools in northeastern Brazil. Análisis de conglomerados de la biomasa relativa ( $\mathrm{mg} / \mathrm{l})$ de las especies de fitoplancton en 20 grupos de rocas, en el Noreste de Brasil.

stochastic demographic events such as birth and mortality rates (Hubbell, 2001; Hubbell, 2005). Both the species and functional group cluster analyses evidenced a similar localized organization of the phytoplankton community in the rock pools, with associations that are characteristic of shallow, nutrient-rich, mixed and turbid environments (Padisak et al., 2009). Accordingly, the two cluster analyses revealed similar morphological groupings, although the functional group-based approach better reflected the environmental conditions, through associations with a high biomass (e.g., functional groups $\mathrm{M}$ and $\mathrm{J}$ in rock pools I, II and VII), as well as with adaptations that are characteristic of bloom-forming filamentous and colonial cyanobacteria and of coccoid and unicellular chlorophytes.

Based on the neutrality theory (Hubbell, 2001; Hubbell, 2005), we can make predictions about the roles of environmental heterogeneity and immigration in a local community structure, with immigration being a key parameter in the pattern of species abundance (Mouquet \& Loreau, 2003). This approach is particularly appropriate for phytoplankton communities, given their large population sizes and rapid renewal rates, which decrease extinction rates and increase the probability of dispersal (e.g., Foissner, 2006).

The high mean values of the Jaccard index $(0.81)$ for species composition and biomass indicated a low similarity and an absence of spatial dependency among the rock-pool communities. The functional groups showed a lower dissimilarity (Jaccard index $=0.57$ ) than the species, indicating that although species are replaced spatially at a high rate, the functional groups remain relatively the same and might exhibit functional redundancy. This suggests that only a few species are resistant to the environmental conditions in these ecosystems, and therefore, the rate of species loss is high, although these losses were compensated by functionally similar species (Loreau, 2004; Joner et al., 2011).

In this study, the isolation among rock pools did not determine the spatial structure of the phytoplankton communities, and therefore geographic distance did not contribute to the spatial organization of the communities. Among community attributes, only species richness showed a positive and significant correlation with distance, i.e., between-pool species richness increased with the increase in distance between pools. This result might indicate that the communities of each rock pool are already saturated and that stable neutral dynamics are operating, i.e., an increase in the biomass of certain functional groups is offset by a decrease in other functional groups that are less adapted to the environmental instability of these habitats. These ecosystems are temporary aquatic islands surrounded by rock formations and typical vegetation of semi-arid regions, with an extremely simple hydrology. 
They are common in areas of low precipitation, high evaporation (Brendonck et al., 2010) and short hydroperiods (Brendonck et al., 2016) and are highly susceptible to desiccation and severe disturbance events. Desiccation and the length of the hydroperiod are determining factors in the occurrence and maintenance of planktonic species (e.g., Vanschoenwinkel et al., 2009; Altermatt et al., 2009; Simões et al., 2011).

A large number of rare species occurred in these rock-pool communities. Regionally rare species are more prone to local extinction (Volkov et al., 2005) than abundant species, which are more likely to immigrate (Chave, 2004). Furthermore, the neutral theory predicts that the similarity in species composition will decrease as the distance between communities increases, indicating a dependence on the effects of limited dispersal (Drakou et al., 2009), as observed in the present study.

Our results suggest that the degree of isolation of rock pools did not influence the rate of species replacement, with different species that fitted the functional niches in the community but that were distributed stochastically among the pools. The synergy between local structuring (size, depth, light limitation) and spatial (dispersal) factors, although often neglected in the general literature, might be the best paradigm for explaining the distribution and structure of phytoplankton communities in these freshwater rock pools.

\section{REFERENCES}

ALTERMATT, F., V. I. PAJUNEN \& D. EBERT. 2009. Desiccation of rock pool habitats and its influence on population persistence in a Daphnia metacommunity. PLoS ONE, 4 (3): 1-11. DOI: 10.137/0004703

ALVARES, C. A., J. L. STAPE, P. C. SENTELHAS, J. L. M. GONÇALVES \& G. SPAROVEK. 2013. Köppen's climate classification map for Brazil. Meteorologische Zeitschrift, 22: 711-728. DOI: 10.1127/09412948

BEISNER, B. E., P. R. PERES-NETO, E. S. LINDSTRÖM, A. BARNETT \& M. L. LONGHI. 2006. The role of environmental and spatial processes in structuring lake com- munities from bacteria to fish. Ecology, 87: 2985-2991. DOI: 10.1890/0012-9658

BRENDONCK, L., M. JOCQUE, A. HULSMANS \& B. VANSCHOENWINKEL. 2010. Pools 'on the rocks': freshwater rock pools as model system in ecological and evolutionary research. Limnetica, 29 (1): 25-40.

BRENDONCK, L., S. LANFRANCO, B. TIMMS \& B. VANSCHOENWINKEL. 2016. Invertebrates in Rock Pools. In: Invertebrates in Freshwater Wetlands. (ed.): 141-189. An International Perspective on Their Ecology, Springer.

CHAVE, J. 2004. Neutral theory and community ecology. Ecology Letters, 7: 241-253. DOI: 10.1111/j.1461-0248.2003.00566.x

COLE, G.A. 1994. Textbook of Limnology. Waveland Press Inc., Prospect Heights, Illinois.

COTTENIE, K. \& L. MEESTER. 2003. Connectivity and cladoceran species richness in a metacommunity of shallow lakes. Freshwater Biology, 48: 823-832.

DRAKOU, E. G., D. C. BOBORI, A. S. KALLIMANIS, A. D. MAZARIS, S. P. SGARDELIS \& J. D. PANTIS. 2009. Fresh water fish community structured more by dispersal limitation than by environmental heterogeneity. Ecology of Freshwater Fish, 18: 369-379. DOI: 10.1111/j.1600-0633.2009.00354.x

FOISSNER, W. 2006. Biogeography and dispersal of microorganisms: a review emphasizing protists. Acta Protozoologica, 45: 111-136.

GENITSARIS, S., K. A. KORMAS \& M. MOUSTAKA-GOUNI. 2011. Airborne algae and cyanobacteria: Occurrence and related health effects. Frontiers in Bioscience, 3: 772-787.

GONZALEZ, A., N. MOUQUET \& M. LOREAU. 2009. Biodiversity as spatial insurance: the effects of habitat fragmentation and dispersal on ecosystem functioning. In: Biodiversity, Ecosystem Functioning and Ecosystem Services. (ed.): 134-146. New York.

HAVEL, J. \& J. B. SHURIN. 2004. Mechanisms, effects, and scales of dispersal in fresh water zooplankton. Limnology and Oceanography, 49: 1229-1238. DOI: 10.4319/1o.2004.49. 4 part 2.1229 
HILLEBRAND, H., C. D. DÜRSELEN, D. KIRSCHTEL, D. POLLINGHER \& $\mathrm{T}$. ZOHARY. 1999. Biovolume calculation for pelagic and benthic microalgae. Journal of Phycology, 35: 403-424. DOI: 10.1046/j.15298817.1999.3520403. $\mathrm{x}$

HUBBELL, S. P. 2001. The Unified Neutral Theory of Biodiversity and Biogeography. Princeton University Press, Princeton, N. J.).

HUBBELL, S. P. 2005. Neutral theory in community ecology and the hypothesis of functional equivalence. Functional Ecology, 19: 166-172. DOI: 10.1111/j.0269-8463.2005. 00965. $\mathrm{x}$

HULSMANS, A., B. VANSCHOENWINKEL, C. PYKE, B. J. RIDDOCH \& L. BRENDONCK. 2008. Quantifying the Hydroregime of a Temporary Pool Habitat: A Modelling Approach for Ephemeral Rock Pools in SE Botswana. Ecosystems, 11: 89-100. DOI: 10.1007/s10021-007-9110-3

HUNTER, T. E. \& A. NOSRATINIA. 2002. Cooperation diversity through coding. Proceedings. IEEE International Symposium on Information Theory, 30 June-5 July 2002, Lausanne, Switzerland: 2002-220.

JACCARD, P. 1908. Nouvelles recherches sur la distribution florale. Bulletin de la Société vaudoise des Sciences naturelles, 44: 223-270.

JATOBÁ, L. 1994. A Geomorfologia do Semiárido Universidade Federal de Pernambuco, Brasil

JENSEN, J.P., E. JEPPESEN, K. OLRIK \& P. KRISTENSEN. 1994. Impact of nutrients and physical factors on the shift from cyanobacterial to chlorophyte dominance in shallow Danish lakes. Canadian Journal of Fisheries and Aquatic Sciences, 5: 1692-1699.

JOCQUE, M. B., B. VANSCHOENWINKEL \& L. BRENDONCK. 2010. Freshwater rock pools: a review of habitat characteristics, faunal diversity and conservation value. Freshwater Biology, 55: 1587-1602. DOI: 10.1111/j.1365-2427.2010.02402.x

JONER, F., G. SPECHT, S. C. MÜLLER \& V. D. PILLAR. 2011. Functional redundancy in a clipping experiment on grassland plant communities. Oikos, 120: 1420-1426. DOI: 10.1111/j.1600-0706.2011.19375.x
JURASINSKII, G. V., Y. C. RETZER \& C. BEIERKUHNLEIN. 2009. Inventory, differentiation, and proportional diversity: a consistent terminology for quantifying species diversity. Oecologia, 159: 15-26. DOI: 10.1007/s10531-016-1093-y

KLUGE, M. \& B. BÜDEL. 2013. Inselbergs: Vegetation, Diversity and Ecology. Tropical Biology and Conservation Management. UNESCO.

LEGENDRE, P. \& L. LEGENDRE. 1998. Numerical Ecology. Second English edition. Elsevier, New York, New York.

LEIBOLD, M. A., M. HOLYOAK, N. MOUQUET, P. AMARASEKARE, J. M. CHASE, M. F. HOOPES, R. D. HOLT, J. B. SHURIN, R. LAW, D. TILMAN \& M. LOREAU. 2004. The metacommunity concept: a framework for multiscale community ecology. Ecology Letters, 7: 601-613.DOI: 10.1111/j.14610248.2004.00608.x

LOREAU, M. 2004. Does functional redundancy exist? Oikos, 104: 606-611.DOI: 10.1111/j. 0030-1299.2004.12685.x

LUND, J. W. G., C. KIPLING \& E. D. LE CREN. 1958. The inverted microscope method of estimating algal numbers and the statistical basis of estimations by counting. Hydrobiologia , 11: 143-170. DOI: 10.1007/ BF00007865

MAGURRAN, A. E. 2004. Measuring Biological Diversity. Blackwell Science, Oxford.

MALTCHIK, L. 2000. As lagoas temporárias do semi-árido. Ciência Hoje, 28 (167): 67-70.

MICHELS, E., K. COTTENIE, L. NEYS \& L. MEESTER. 2001. Zooplankton on the move: first results on the quantification of dispersal of zooplankton in a set of interconnected ponds. Hydrobiologia, 442: 117-126. DOI: 10.1023/A:1017549416362

MOUQUET, N. \& M. LOREAU. 2003. Community patterns in source-sink metacommunities. The American Naturalist, 162 (5): 318-331. DOI: $10.1086 / 378857$

PADISÁK, J., L. O. CROSSETTI \& L. NASELLIFLORES. 2009. Use and misuse in the application of the phytoplankton functional classification: a critical review with updates. $H y d-$ robiologia, 62: 1-19. DOI: 10.1007/s10750- 
008-9645-0

PIELOU, E. C. 1966. The measurement of diversity in different types of biological collections. Journal of Theoretical Biology, 13: 131-144. DOI: 10.1016/0022-5193

POOLE, H. H. \& W. R. G. ATKINS. 1929. Photo-electric measurements of submarine illumination throughout the year. Journal of the Marine Biological Association of India, 16: 297-324. DOI: $10.1017 / \mathrm{S} 0025315400029829$

POREMBSKI, S. 2007. Tropical inselbergs: habitat types, adaptive strategies and diversity patterns. Brazilian Journal of Botany, 30: 579-586. DOI: 10.1590/S0100-84042007000400004

R CORE TEAM. 2017. R: A Language and Environment for Statistical Computing.

REYNOLDS, R. C., V. HUSZAR, C. KRUK, L. NASELLI-FLORES \& S. MELO. 2002. Towards a functional classification of the freshwater phytoplankton. Journal of Plankton Research, 24: 417-428. DOI: 10.1093/ plankt/24.5.417

SHANNON, C. E. \& W. WEAVER. 1963. The Mathematical Theory of Communication. University of Illinois Press, Urbana, Illinois.

SHURIN, J. B., J. E. HAVEL, M. A. LEIBOLD $\&$ B. PINEL-ALLOUL. 2000. Local and regional zooplankton species richness: A scale independent test for saturation. Ecology, 81: 3062-3073. DOI: 10.2307/177401

SHURIN, J. B. \& D. S. SRIVASTAVA. 2005. New perspectives on local and regional diversity: beyond saturation. In: Metacommunities: Spatial Dynamics and Ecological Communities. (ed.): 399-417. University of Chicago Press, Chicago, Illinois.

SIMÕES, L. C., M. LEMOS, P. ARAÚJO, A. M. PEREIRA, M. SIMÕES. 2011. The effects of glutaraldehyde on the control of single and dual biofilms of Bacillus cereus and Pseudomonas fluorescens. Biofouling, 27: 337-346. DOI: 10.1080/08927014.2011.575935

SNEATH, P. H. A. \& R. R. SOKAL. 1973. Numerical Taxonomy: The Principles and Practice of Numerical Classification. San Francisco, Freeman.
SOININEN, J., M. KOKOCINSKI, S. ESTLANDER, J. KOTANEN \& J. HEINO. 2007. Neutrality, niches, and determinants of plankton metacommunity structure across boreal wetland ponds. Ecoscience, 14: 146-154. DOI: $10.2980 / 1195-6860$

SUN, J. \& D. LIU. 2003. Geometric models for calculating cell biovolume and surface area for phytoplankton. Journal of Plankton Research, 25: 1331-1346. DOI: 10.1093/plankt/fbg096

UTERMÖHL, H. 1958. Zur Vervollkommnung der quantitativen Phytoplankton-Methodik. Mitteilungen der Internationale Vereinigung für Theoretische und Angewandte Limnologie, 9: 1-38.

VANORMELINGEN, P., K. COTTENIE, E. MICHELS, K. MUYLAERT, W. VYVERMAN \& L. DE-MEESTER. 2008. The relative importance of dispersal and local processes in structuring phytoplankton communities in a set of highly interconnected ponds. Freshwater Biology, 53: 2170-2183. DOI: $10.1111 / \mathrm{j} 1365-2427.2008 .02040 . x$

VANSCHOENWINKEL, B., A. HULSMANS, E. R. DE ROECK, C. DE VRIES, M. SEAMAN \& L. BRENDONCK. 2009. Community structure in temporary freshwater pools: disentangling the effects of habitat size and hydroregime. Freshwater Biology, 54 (7): 1487-1500. DOI: $10.1111 /$ j.1365-2427.2009.02198.x

VOLKOV, I., J. BANAVAR, R. JAYANTH, S. P.HUBBELL \& A. MARITAN. 2005. Density dependence explains tree species abundance and diversity in tropical forests. Nature, 438: 658-651. DOI: 10.1038/nature04030

WHITTAKER, R. H. 1972. Evolution and measurement of species diversity. Taxon, 21: 213-251.DOI: $10.2307 / 1218190$

WILLIAMS, D. D. 1997. Introduction to temporary waters. In: The Ecology of Temporary Waters. (ed.): 1-3. Timber Press, Portland, Maine.

WINEGARDNER, A. K. 2012. The terminology of metacommunity ecology. Trends in Ecology \& Evolution, 27: 253-254. DOI: 10.1016/j. tree.2012.01.007 